\title{
STUDENTS' MOTIVATIONS TOWARD CHOOSING ENGLISH EDUCATION
}

\author{
Choiril Anwar \\ English Education Department, Faculty of Language and Communicaion Science, Universitas Islam \\ Sultan Agung, Indonesia \\ E-mail: choirilanwar@unissula.ac.id \\ Kurniawan Yudhi Nugroho \\ English Education Department, Faculty of Language and Communicaion Science, Universitas Islam \\ Sultan Agung, Indonesia \\ E-mail: kurniawan@unissula.ac.id
}

APA Citation: Anwar, C., \& Nugroho, K. Y. (2018). Students' motivations toward choosing English education. Indonesian EFL Journal, 4(1), 57-64. DOI: 10.25134/ieflj.v4i1.799.

Published: 01-01-2018

\begin{abstract}
Motivation, almost at all aspects, gives a big impact for senior high school students to choose a major or study program at a university. The motivation itself can be both intrinsic and extrinsic. This study aims to investigate the motivation of students to choose English Education department at university. The subjects of this research were 37 students majoring English Education at Sultan Agung Islamic University (UNISSULA) Semarang, Indonesia. This is descriptive quantitative research. Observations and questionnaires were used to collect the data needed. The data were then analyzed by using descriptive statistical analysis. As results, it was found that $81.1 \%$ of the students of English Education have strong intrinsic motivation which leads them to choose English Education as their major. This selection was due to students' curiosity and passion to increase their potential and skills in English.
\end{abstract}

Keywords: English education, students' motivation, university

\section{INTRODUCTION}

English in this global era plays an important role in scientific development. Any science will require a person's English skills, more especially for students. To learn a certain theory, a student should seek references about it and most references use English as their introductory language.

However, in fact, at Sultan Agung Islamic University (UNISSULA) Semarang, the English Department of Education is still not as popular as other departments, such as Medical department, Nursing, Dentistry, Accounting, Management, Psychology, Civil Engineering, and so forth. Most of the students in these departments argued that English can be learnt autodidactically or simply by taking a course, without having to go to English Education department. Moreover, they are not interested in becoming teachers.
Indeed, every student surely has a diverse motivation in choosing a major or course of study. Students who choose the Medical department in UNISSULA may be motivated that someday they can become doctors at Sultan Agung Islamic Hospital (the same foundation as UNISSULA). Those who choose Civil Engineering department may be motivated that someday they can follow in the footsteps of their predecessors who won the world's robotic championship.

Motivation, actually, is a change in the energy of a person characterized by the emergence of feelings (Sardiman, 2007) and reaction (Djamarah, 2008) to achieve the goal. While Uno (2006) states that motivation is a psychological process that can explain a person's behavior, the power that drives someone to do something. These forces are essentially stimulated by the existence of 
various needs, such as the desire to be fulfilled, behavior, purpose, and feedback.

Motivation and learning are two things that affect each other. Motivation to learn can arise because of intrinsic factors, in the form of passion and willingness to succeed and the impulse of learning needs. While extrinsic factors can include awards, a conducive learning environment, and interesting learning activities (Uno, 2006). Most researchers would probably agree that motivational terms mean the direction and magnetism of human behavior, its relation to the choice of certain actions, persistence, and effort. In other words, motivation is very much about why people decide to do something, how long they will continue to do the activity, and how seriously they will pursue it.

One's motivation in choosing a study program or course of study is closely related to their motivation to learn a foreign language. According to Gardner's (1985) theory, one's motivation in learning foreign language is based on three elements, namely: 1) motivational effort or intensity, 2) the desire to learn the language, and 3) his attitude in learning the language.

Both motivation and orientation are interconnected with each other. Orientation exists before motivation. In relation to learning a foreign language, two terms of orientation are known as follows (Dörnyei \& Ushioda, 2011):

a. Integrative Orientation : Gardner \& Lambert (1972) define intergrative orientation as "the willingness to be regarded equally in members of the language community." In this orientation, a person really wants to learn a foreign language in order to improve his or her foreign language skills so that later he is considered the same as a particular language community.

b. Instrumental Orientation : This orientation is more pragmatic. For example, one chooses to learn a foreign language because he wants to get a decent job or earn a higher salary.

Motivation which became the main concern of researchers was the motivation of the students choosing English Education
Department since this department is now not so prestigious in the eyes of most high school graduates' minds. In addition, since foreign language can be studied alone, they are not interested to become English teachers who are now increasingly limited since there has been no implementation of English as subjects in Primary Schools as other subjects. In fact, there are still high school graduates who have an interest into English Education Department in Faculty of Language and Communication science UNISSULA. This underlies the researchers to do research on how and what motivation of students choose English Education study program.

One of similar researches on motivation has been done by Ying, Suprayogi, \& Hurriyati (2013). In rheir study, the variables used were the motivation to learn Mandarin as a second language. A total of 276 respondents were chosen by purposive sampling from three universities, namely students majoring in Mandarin Literature at Bina Nusantara University Jakarta, Darma Persada University Jakarta, and University of North Sumatra Medan. The research also involved the Chinese Language and Literature Faculty of Huaqiau University of China as a partner in the preparation of research instruments. Descriptive analysis was conducted to explore the main motivation underlying Mandarin Chinese students and then to do different test for knowing the difference of motivation between students of Chinese descent and native students. The results showed that the motivation of respondents in learning Mandarin was relatively low. There was no significant difference between integrative and instrumental motivation. The intensity motivation was relatively higher compared to the integrative and instrumental. Likewise, there is no significant difference in motivation between Chinese and non-Chinese students in learning Mandarin. Lecturers, therefore, need to improve teaching methods to improve students' learning motivation in learning Mandarin.

Another related research was conducted by Moskovsky \& Alrabai (2009). The paper presents an experimental study purposed to measure levels of intrinsic motivation in 
learners of English as a Foreign Language in Saudi Arabia. Data collected through the survey were subjected to some basic statistical analyses, such as mean and standard deviation. Based on the results from the analysis, a number of generalizations and conclusions were made in relation to the role of motivation in the attainment of English as a foreign language in the Saudi educational setting. In addition, some recommendations are offered, which may enable Saudi teachers and learners of English as a foreign language to achieve better learning outcomes in an area widely associated by Saudis with lack of success.

Therefore, the problems raised in this research are 1) What are the students' motivations in batch 2015 and 2016 choose the English Education department in Faculty of Language and Communication science UNISSULA? 2) What is the main motivation for students in batch 2015 and 2016 to choose English Education at Faculty of Language and Communication science UNISSULA?

Specific targets to be achieved in this research is that by knowing the motivation of students to choose the English Education department, then this result can be used as a reference for the Faculty of Language and Communication science UNISSULA and other universities in Indonesia to improve service performance to students. In addition, the results of this study can also be a reference for Ministry of Research and Higher Education of Indonesia (Ristekdikti) to review the prospects and significance of this department for knowledge. Last but not least, this research will be useful for wider range of society in Indonesia.

\section{METHOD}

This research used quantitative descriptive method. In descriptive research or survey research, in addition to trying to determine and describe something, the researchers also compared how the problems of sub-groups (Airasian, 2000). In this study, the researchers conducted a survey by using questionnaires to students of English Education Study program class of 2015 and 2016 about their motivation to choose English Education Study Program.
From these results, the researcher then made a percentage of how much each item of the question gets a response and ultimately, among the motivations, what is the motivation that gets the highest percentage as the main motivation of the student.

This research was conducted at the Faculty of Language and Communication Science of Sultan Agung Islamic University (UNISSULA) Semarang. It was descriptive quantitative using survey method with observation and questionnaire, which means the survey results on the subject of research were analyzed with descriptive statistics.

The population of this study were 206 undergraduate students of English Education program at Faculty of Languages and Communication Science of Sultan Agung Islamic University (UNISSULA) Semarang. From that number, the sample was taken as many as 37 students, especially batch 2015 and 2016 by using purposive sampling. It was in line with Airasian (2000) stating that if researchers select the sample based on experience or knowledge of the group to be sampled, they are using purposive sampling technique. The instrument used in this study was an online questionnaire. The questionnaire was made by researchers online by using Google Forms. There were 17 items of questions: five items were kinds of introductory questions (students' faculty, batch, name, information, and study program), while the rests were intrinsic motivation questions ( 2 items) and extrinsic motivation questions (10 items) —one of them was open ended question $(\mathrm{J})$. The remarks were about the motivations underlying their choice of English Education study program rather than other departments in UNISSULA.

The data collected from the questionnaire were then analyzed and interpreted in depth and then described in details by the researcher. The results of the analysis would be as a reference for the conclusion and its research report.

\section{RESULTS AND DISCUSSION}

This section covers the research findings and the discussion. As stated above, there 


\section{Choiril Anwar \& Kurniawan Yudhi Nugroho}

Students' motivations toward choosing English education

were 17 items of questions: five items were introductory questions (students' faculty, batch, name, information, and study program) as written in $\mathrm{A}, \mathrm{B}, \mathrm{C}, \mathrm{D}$, and $\mathrm{E}$, while the rests were intrinsic motivation questions ( 2 items) as seemed in $\mathrm{F}$ and $\mathrm{G}$, and extrinsic motivation questions (10 items) — one of them was open ended question $(\mathrm{J})$.

\section{a. Respondent}

Nama (boleh inisial):
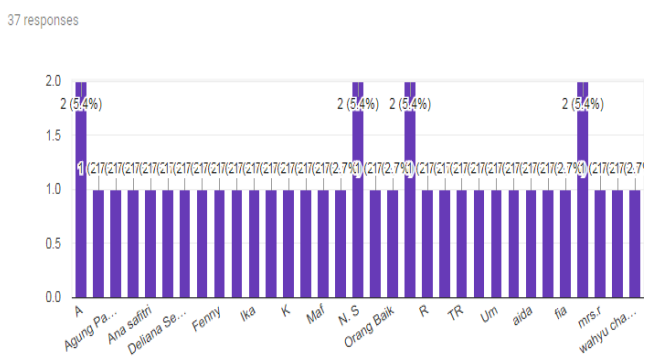

Figure 1. respondents' names

The picture shows that the researchers gave freedom to the respondents (students) to type or not to type their names to keep their identity confidential. Some students then used their nicknames or initials.

\section{b. Study Program}

Jurusan/Prodi
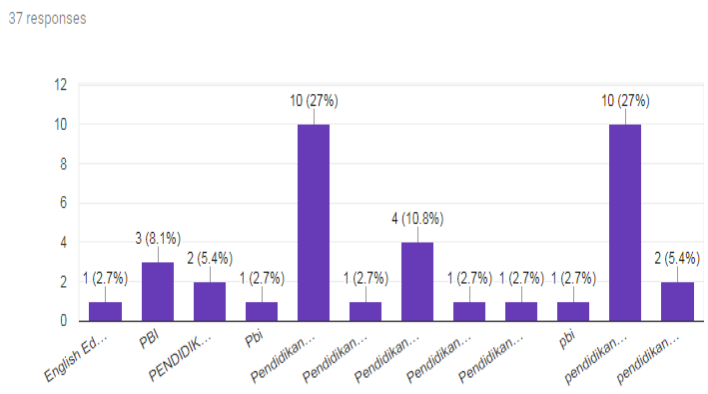

Figure 2. Respondents' study program

The image has convinced the reader that all respondents in this study were students of English Education Study Program.

\section{c. Faculty}

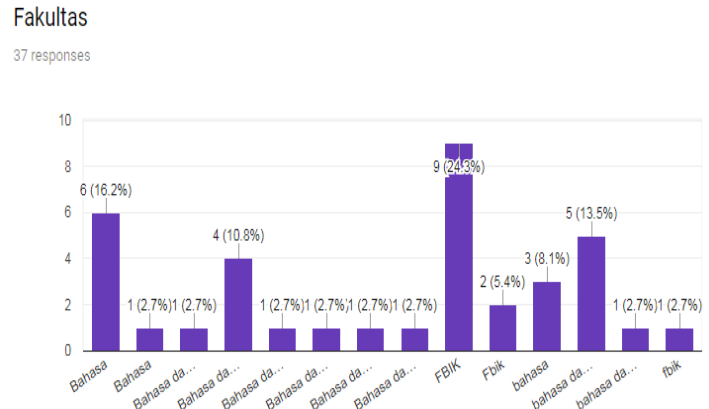

Figure 3. Respondents' faculty

The picture shows that all respondents from this research were from Faculty of Languages and Communication science, UNISSULA.

\section{d. Batch}

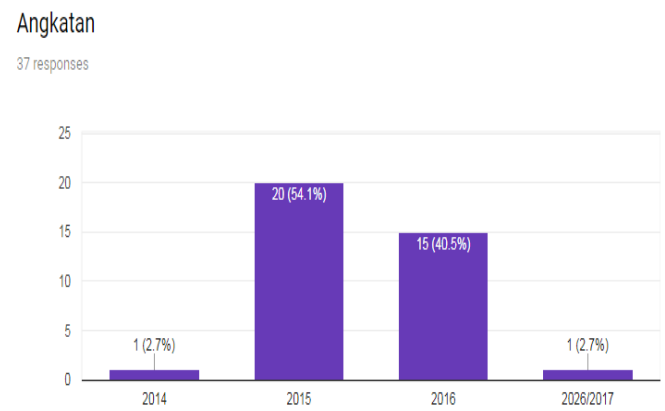

Figure 4. Respondents' batch

The picture shows that all respondents from this study were students of English Education course of class of 2015 and 2016, except one from class of 2014 who re-take the class in the following batch.

\section{e. Information on Study Program}

Dari manakah Anda mendapatkan informasi tentang PBI UNISSULA? 37 responses
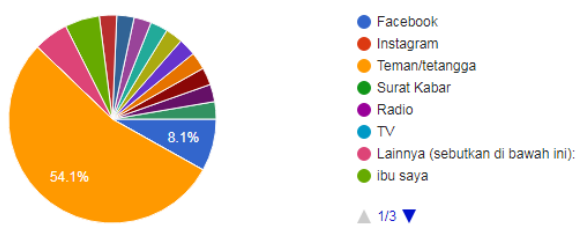

Figure 5. Information on Study Program (Question: Where did you get the information of PBI UNISSULA?) 
The picture describes the respondents' response that the information about PBI UNISSULA at most $(54.1 \%)$ comes from friends or neighbors.

\section{f. Students' interest}

Apakah Anda memilih jurusan PBI karena Anda punya MINAT BESAR (suka) dengan Bahasa Inggris?
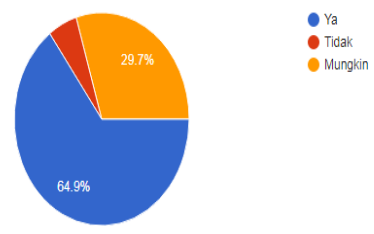

Figure 6. Students' interest

(Question: Did you choose PBI department because you had high interest in English?)

From the figure, it can be concluded that there are $64 \%$ of respondents who stated that they choose English Education study program because they have great interest in English.

\section{g. Curiosity}

Apakah Anda memilih jurusan PBI karena Anda punya RASA INGIN TAHU YANG BESAR dengan Bahasa Inggris (Anda ingin meningkatkan potensi/kualitas Bahasa Inggris Anda)?

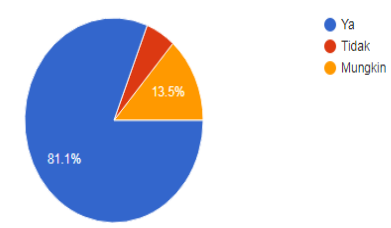

Figure 7. Curiosity

(Question: Did you choose PBI because you are really curious on English (you really like to improve your English skills)?)

Meanwhile, the figure shows that $81.1 \%$ of respondents stated they chose English Education course because they have great curiosity on English. They want to improve the potential and quality of their English.

\section{h. Parents' Encouragment}

Apakah Anda memilih jurusan PBI karena dorongan dari ORANGTUA?
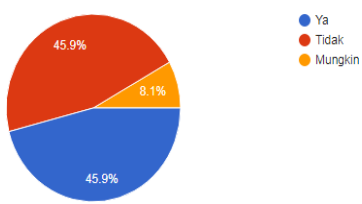

Figure 8. Parents' Encouragment (Question: Did you choose PBI because of your parents?)

From the figure above it can be concluded that $45 \%$ of respondents chose PBI department because of the encouragement of their parents.

\section{i. Friend's Encouragment}

Apakah Anda memilih jurusan PBI karena dorongan dari TEMAN sekolah Anda?

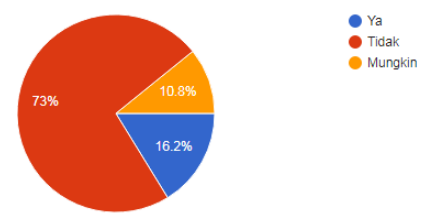

Figure 9. Friend's Encouragment

(Question: Did you choose PBI because of your college friends?)

While being asked whether they chose PBI because of their schoolmates, as shown in Figure 10, most of students answered "no" (73\%). Only $16.2 \%$ of respondents replied "yes".

\section{j. Institution's Appeals}

Apa saja hal baik (sangat menarik bagi Anda) yang pernah Anda dengar dari orang lain (iklan, info dari teman dII) tentang PBI UNISSULA sebelum memilih untuk mengambil jurusan ini?

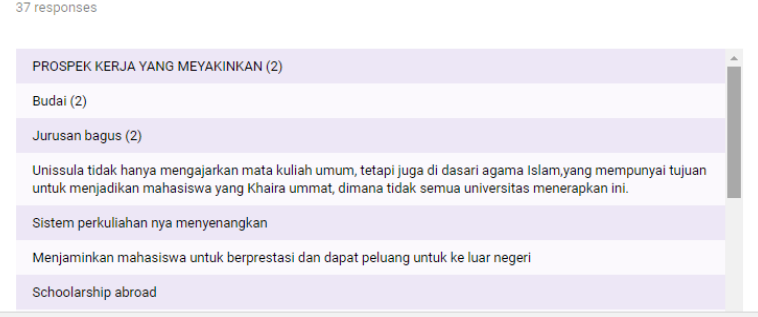




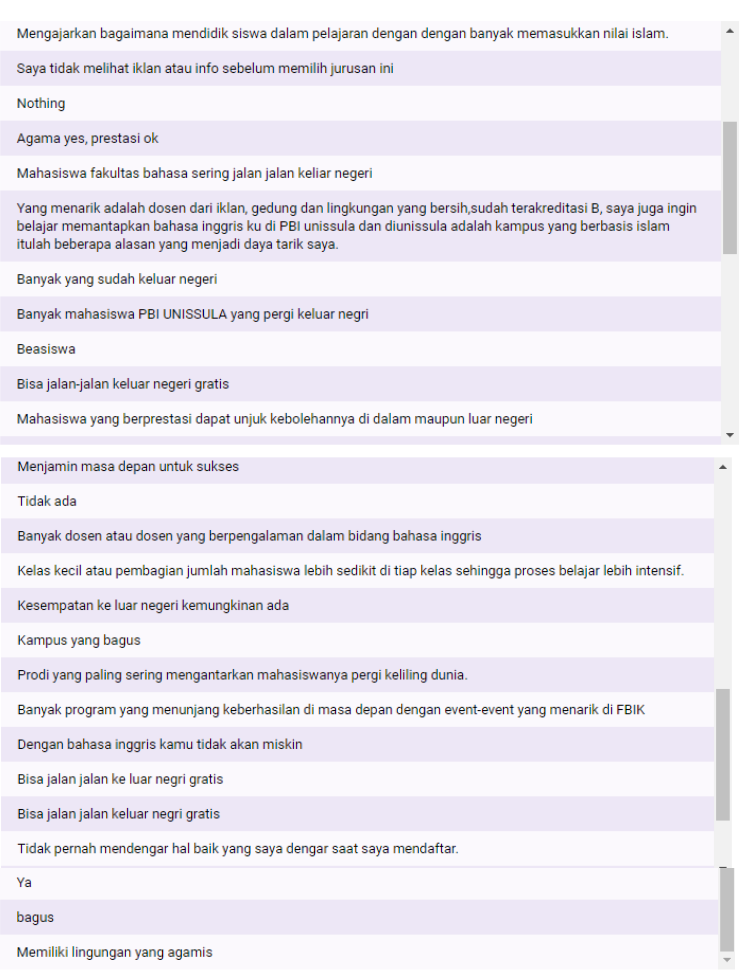

Figure 10. Institution's appeal

(Question: What are good things you have heard about PBI UNISSULA?)

Many good things that the respondent finds (both from ads etc.) before choosing PBI UNISSULA. Most of them chose PBI because the religious environment, "lure" eased them to follow the program abroad because many students in this program who have done it before.

\section{k. Lecturer}

Apakah dosen/pengajar (dari iklan, teman dII) di PBI UNISSULA menjadi daya tarik Anda sebelum memilih jurusan ini?
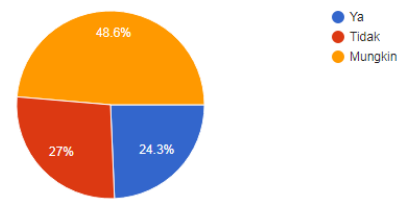

Figure 11. Lecturer

(Question: Is UNISSULA lecturer be your appeal to choose PBI?)

Most of the respondents were not sure if they chose PBI study program because of the PBI lecturers. As it can be seen on the figure that there was only $24.3 \%$ of respondents who answered "yes."

\section{l. University Environment}

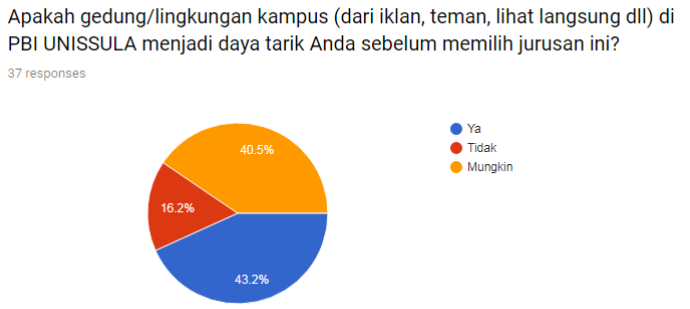

Figure 12. University environment (Question: is the campus physical environment (building etc) be your appeal to choose PBI?)

Physical environment of the campus (building etc.) became the attractiveness of respondents in choosing PBI UNISSULA, but not too many. It is because there was only $43.2 \%$ of respondents who answered "Yes".

\section{m. Alumni}

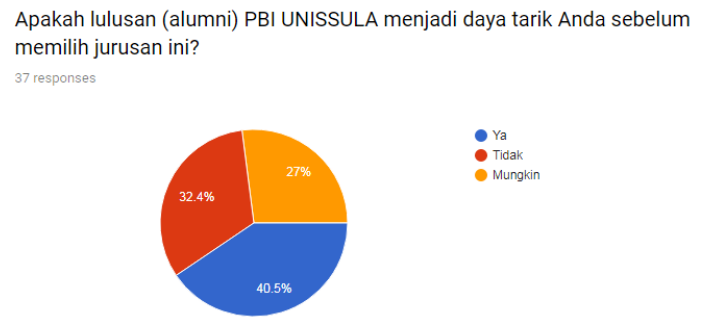

Figure 13. Alumni

(Question: is the alumni be your appeal to choose PBI?)

Alumni PBI was less enough (40.5\%) to attract respondents to choose PBI.

\section{n. Student's Factor}

Apakah teman (yang kuliah) di PBI UNISSULA menjadi daya tarik Anda sebelum memilih jurusan ini?

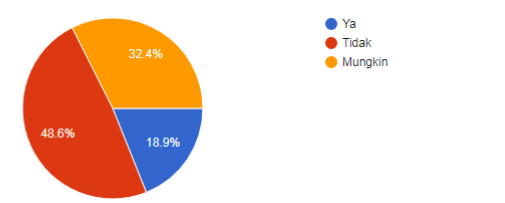

Figure 14. Student's Factor (Question: is your friend in PBI be your appeal to choose PBI?)

However, friends (who are still active college) does not attract them to choose the PBI study program. It was proved that there was only $18.9 \%$ responded "Yes". 


\section{o. Administration and Teaching Service}

Apakah pelayanan (baik administrasi maupun pelayanan pengajaran yang maksimal) di PBI UNISSULA menjadi daya tarik Anda sebelum memilih jurusan ini?

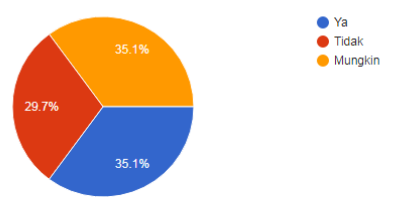

Figure 15. Administration and Teaching Service

(Question: is the administration and teaching service be your appeal to choose PBI?)

Because respondents do not know how the actual administrative and teaching services are on campus, the respondents answered "yes", "no", and "maybe". Each has almost the same percentage.

\section{p. Institutional Guarantee}

Apakah jaminan yang diinformasikan di iklan (pekerjaan dII) PBI UNISSULA menjadi daya tarik Anda sebelum memilih jurusan ini?
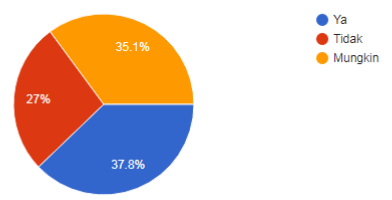

Figure 16. Institutional Guarantee
(Question: is the institutional guarantee be your appeal to choose PBI?)

Likewise with the warranty informed in the ad, each has the same percentage of answers.

\section{q. Tuition Fee}

Apakah biaya kuliah di PBI UNISSULA menjadi daya tarik Anda sebelum memilih jurusan ini?

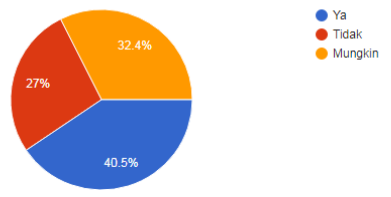

Figure 17. Tuition Fee

(Question: is tuition fee in UNISULLA be your appeal to choose PBI?)

Tuition fees do not really affect their choice of PBI. It was poved by the results of two diagrams above stating that the costs listed are still affordable by them (their families.

Table 1. Summary of Students' Intrinsic and Extrinsic Motivation in Choosing English Education

\begin{tabular}{|c|c|c|c|c|c|}
\hline \multirow{2}{*}{$\begin{array}{l}\text { Number } \\
\text { /Letter }\end{array}$} & \multirow[t]{2}{*}{ Items } & \multirow{2}{*}{$\begin{array}{c}\text { Kinds of } \\
\text { Motivation }\end{array}$} & \multicolumn{3}{|c|}{ The Response (\%) } \\
\hline & & & Yes & No & Probably \\
\hline $\mathbf{F}$ & $\begin{array}{l}\text { Did you choose PBI } \\
\text { department because you } \\
\text { had high interest to } \\
\text { English? }\end{array}$ & $\begin{array}{l}\text { Intrinsic } \\
\text { motivation }\end{array}$ & 64 & 5.9 & 29.7 \\
\hline G & $\begin{array}{l}\text { Did you choose PBI } \\
\text { because you are really } \\
\text { curious with English (you } \\
\text { really like to improve your } \\
\text { English skills)? }\end{array}$ & & 81.1 & 5.4 & 13.5 \\
\hline $\mathbf{H}$ & $\begin{array}{l}\text { Did you choose PBI } \\
\text { because of your parents? }\end{array}$ & $\begin{array}{l}\text { Extrinsic } \\
\text { Motivation }\end{array}$ & 45.9 & 45.9 & 8.1 \\
\hline $\mathbf{I}$ & $\begin{array}{l}\text { Did you choose PBI } \\
\text { because of your college } \\
\text { friends? }\end{array}$ & & & & \\
\hline $\mathbf{J}$ & $\begin{array}{l}\text { What are good things you } \\
\text { have heard about PBI } \\
\text { UNISSULA? }\end{array}$ & & \multicolumn{3}{|c|}{$\begin{array}{l}\text { Various responses (no } \\
\text { dominant one) }\end{array}$} \\
\hline $\mathbf{K}$ & $\begin{array}{l}\text { Is lecturer the appeal for } \\
\text { you to choose PBI? }\end{array}$ & & 24.3 & 27 & 48.6 \\
\hline $\mathbf{L}$ & $\begin{array}{l}\text { is the campus physical } \\
\text { environment (building etc) } \\
\text { the appeal to choose PBI? }\end{array}$ & & 43.2 & 16.2 & 40.5 \\
\hline $\mathbf{M}$ & $\begin{array}{l}\text { is the alumni the appeal to } \\
\text { choose PBI? }\end{array}$ & & 40.5 & 32.4 & 27 \\
\hline
\end{tabular}


Choiril Anwar \& Kurniawan Yudhi Nugroho

Students' motivations toward choosing English education

\begin{tabular}{|c|c|c|c|c|}
\hline $\mathbf{N}$ & $\begin{array}{l}\text { is your friend in PBI the } \\
\text { appeal for you to choose } \\
\text { PBI? }\end{array}$ & 18.9 & 48.6 & 32.4 \\
\hline O & $\begin{array}{l}\text { is the administration and } \\
\text { teaching service the } \\
\text { appeal for you to choose } \\
\text { PBI? }\end{array}$ & 35.1 & 29.7 & 35.1 \\
\hline $\mathbf{P}$ & $\begin{array}{l}\text { is the institutional } \\
\text { guarantee the appeal for } \\
\text { you to choose PBI? }\end{array}$ & 37.8 & 27 & 35.1 \\
\hline $\mathbf{Q}$ & $\begin{array}{l}\text { is tuition fee appeal for } \\
\text { you to choose PBI } \\
\text { (because of ots } \\
\text { affordability)? }\end{array}$ & 40.5 & 27 & 32.4 \\
\hline
\end{tabular}

From the collection of data taken from 37 English department students of Sultan Agung Islamic University, it was finally found that in terms of intrinsic motivation (written in $\mathrm{F}$ and $\mathrm{G}$ indicators), there were $64 \%$ students stated that they chose English education department (PBI) of UNISSULA because they were really interested in English and most of students $(81.1 \%)$ of PBI students had strong intrinsic motivation that they chose English education department due to their curiosity and a strong willingness to enhance their potential and skills in English. Whereas, in terms of extrinsic motivations (building, tuition fee, parents, friends, lecturer, service, alumni, institutional guarantee, and so forth) were not so dominant in determining their choice when choosing PBI study program. They were vividly seen from the number of its percentage - no one reached $50 \%$. In short, intrinsic motivation factors were higher than extrinsic ones.

\section{CONCLUSION}

From analysis, it was finally found that $81.1 \%$ of the students of the PBI batch 2015 and 2016 had strong intrinsic motivation that they chose the PBI were due to curiosity and a strong willingness to increase their own potential and skills in English. It can be said, the motivation from "inside" (intrinsic) has a strong influence in the selection of courses. Her or his extrinsic motivation just follows it.
The researchers then recommend that this kind of motivational research can be further deepened into experimental research to find motivational effectiveness in student achievement and quality of student English skills. Besides, the reserchers also plan to conduct another research on each kind of motivation (either intrinsic or extrinsic motivation).

\section{REFERENCE}

Airasian, P. (2000). Educational research: Competencies for analysis and application ( $6^{\text {th }} \mathrm{ed}$.). New Jersey: Prentice-Hall, Inc.

Djamarah, S. (2008). Psikologi belajar (Edisi 2). Jakarta: Rineka Cipta.

Dörnyei, Z., \& Ushioda, E. (2011). Teaching and researching motivation ( $2^{\text {nd }}$ ed.). Great Britain: Pearson Education Limited.

Gardner, R. (1985). Social psychology and second language learniing: The role of attitudes and motivation. London: Edward Arnold.

Gardner, R., \& Lambert, W. (1972). Attitudes and motivation in second language learning. MA: Newbury House.

Moskovsky, C., \& Alrabai, F. (2009). Intrinsic motivation in Saudi learners of English as a foreign language. The Open Applied Linguistics Journal, 2, 1-10.

Sardiman, A. (2007). Interaksi dan motivasi belajar mengajar. Jakarta: Raja Grafindo.

Uno, H. B. (2006). Teori motivasi \& pengukurannya: Analisis di bidang pendidikan. Jakarta: PT Bumi Aksara.

Ying, Y., Suprayogi, N., \& Hurriyati, E. (2013). Motivasi belajar bahasa Mandarin sebagai bahasa kedua. Humaniora, 4(2), 1-10. 